\title{
IL-10 release by bovine epithelial cells cultured with Trichomonas vaginalis and Tritrichomonas foetus
}

\author{
Ricardo Chaves Vilela ${ }^{1,3}$, Marlene Benchimol'²/+ \\ 1Programa de Pós-Graduação em Ciências Biológicas, Instituto de Biofísica Carlos Chagas Filho, \\ Universidade Federal do Rio de Janeiro, Rio de Janeiro, RJ, Brasil ²Universidade Santa Úrsula, Rio de Janeiro, RJ, Brasil \\ ${ }^{3}$ Diretoria de Programas, Instituto Nacional de Metrologia, Normalização e Qualidade Industrial, Duque de Caxias, RJ, Brasil
}

Trichomonas vaginalis and Tritrichomonas foetus are parasitic protists of the human and bovine urogenital tracts, respectively. Several studies have described the cytotoxic effects of trichomonads on urogenital tract epithelial cells. However, little is known about the host cell response against trichomonads. The aim of this study was to determine whether $\mathrm{T}$. foetus and $\mathrm{T}$. vaginalis stimulated the release of the cytokine interleukin (IL)-10 from cultured bovine epithelial cells. To characterise the inflammatory response induced by these parasites, primary cultures of bovine oviduct epithelial cells were exposed to either T. vaginalis or T. foetus. Within $12 \mathrm{~h}$ after parasite challenge, supernatants were collected and cytokine production was analysed. Large amounts of IL-10 were detected in the supernatants of cultures that had been stimulated with $\mathrm{T}$. foetus. Interestingly, T. vaginalis induced only a small increase in the release of IL-10 upon exposure to the same bovine cells. Thus, the inflammatory response of the host cell is species-specific. Only $\mathrm{T}$. foetus and not $\mathrm{T}$. vaginalis induced the release of IL-10 by bovine oviduct epithelial cells.

Key words: T. vaginalis - T. foetus - cytokines - host-cells - IL-10

Human and bovine trichomoniases are sexually transmitted diseases caused by the parasites Trichomonas vaginalis and Tritrichomonas foetus, respectively. These parasites are capable of causing severe vaginal, prostatic and urethral inflammation, which are linked to infertility and adverse pregnancy outcomes in their hosts (BonDurant 2005, Johnston \& Mabey 2008). T. vaginalis infection typically elicits aggressive, local cellular immune responses that cause inflammation in the vaginal epithelium and ectocervix in women and in the urethra in men (Shafir et al. 2009). There are few studies that address the responses of host cells to $T$. vaginalis and $T$. foetus infection. Some reports have shown that the cytokines interleukin (IL)-8 and tumour necrosis factor (TNF)- $\alpha$ are secreted when host cells are exposed to specific molecules from $T$. vaginalis (Bastida-Corcuera et al. 2005, Fichorova et al. 2006). Even HeLa cells cultured with this parasite have been reported to secrete some cytokines (Chang et al. 2006).

To verify the response of host cells to trichomonad infection, a primary culture of bovine epithelial cells (BOECs) was grown to model host cells, following previously published procedures (Midlej et al. 2009). The JT strain of T. vaginalis (Fig. 1A) and the $\mathrm{K}$ strain of T. foetus (Fig. 1B) were used as models for human and bovine parasites, respectively. Parasites were cultivated in trypticaseyeast extract-maltose (TYM) medium (Diamond 1957)

\footnotetext{
Financial support: CNPq, FAPERJ, CAPES, PRONEX, AUSU

+ Corresponding author: marlenebenchimol@gmail.com

Received 28 January 2012

Accepted 18 July 2012
}

supplemented with $10 \%$ foetal bovine serum. Host cell cultures were exposed to a parasite:BOECS cell ratio of 5:1 for $12 \mathrm{~h}$ in $37^{\circ} \mathrm{C}$ (Fig. 1C, D). Cells were equilibrated in incubation medium for $5 \mathrm{~min}$ at $37^{\circ} \mathrm{C}\left(5 \% \mathrm{CO}_{2}\right)$ prior to parasite addition. The medium contained two parts of complete DMEM ( $\mathrm{pH}$ 7.2) and one part TYM medium (W/D 2:1) without serum. The incubation medium and temperature were chosen after testing parasite and host cell viabilities in several different conditions. The supernatants of cultures with parasites or without (controls) were collected and cytokine levels were quantified with specific kits for measuring IL-10 (Becton Dickinson, Franklin Lakes, NJ, USA), which were used according to the manufacturers' instructions. The analyses demonstrated that BOECs secrete a large amount of IL-10 after $12 \mathrm{~h}$ of stimulation with the bovine parasite, T. foetus. Compared to control cells, parasite-exposed cells released approximately nine-fold more IL-10 (Fig. 2). However, when the BOECs were exposed to the human parasite, $T$. vaginalis, the levels of IL-10 remained at baseline and increased only slightly compared to controls (Fig. 2).

Previous in vitro studies revealed that exposure to T. vaginalis stimulated IL-8 secretion in human neutrophils (Ryu et al. 2004), in human monocytes (Shaio et al. 1995) and in human vaginal cells (Singh et al. 2009). Moreover, these studies revealed that cytokine secretion was dependent on NF- $\kappa$ B. It was further demonstrated that the cytokines IL-2 and interferon (IFN)- $\gamma$ were secreted by murine lymphocytes infected with $T$. vaginalis (Kirch et al. 2004). In addition, T. vaginalis also stimulated the secretion of TNF- $\alpha$, IL-1 $\beta$ and IL- 6 by human macrophages (Han et al. 2009).

In this study, increased IL-10 was detected in the supernatants of bovine host cell cultures exposed to $T$. foetus. It is important to mention that IL-10 was also detected in previous studies of dendritic cells and macrophages 


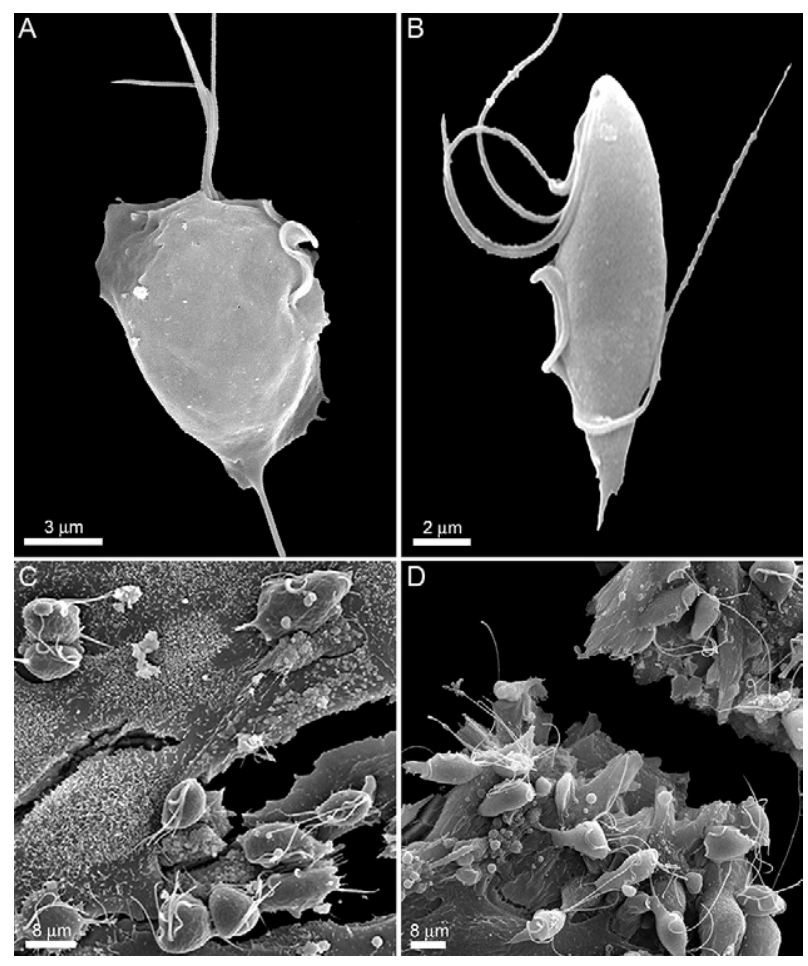

Fig. 1: scanning electron microscopy images of Trichomonas vaginalis JT (A) and Tritrichomonas foetus K (B). The parasites are adhered to bovine epithelial cells after $12 \mathrm{~h}$ of interaction. C: T. vaginalis; D: T. foetus.

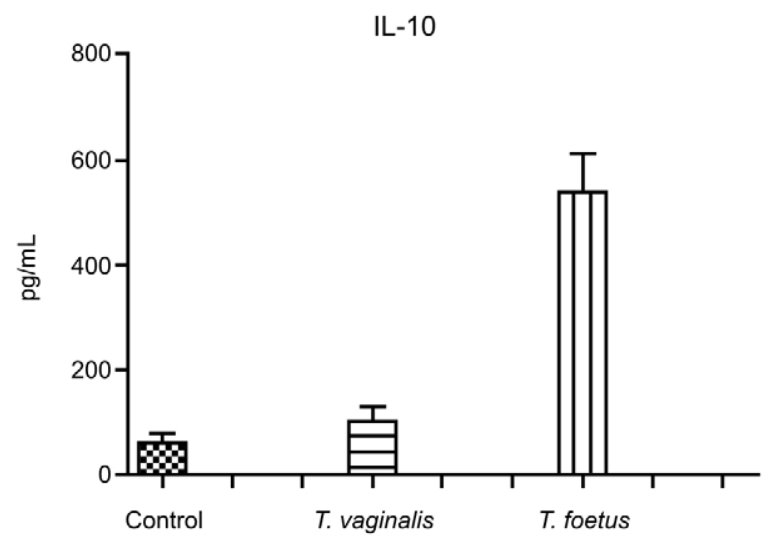

Fig. 2: interleukin (IL)-10 production by bovine epithelial cells before (control) and after interaction with Trichomonas vaginalis and Tritrichomonas foetus. Note that $T$. foetus, but not $T$. vaginalis, stimulates IL-10 production by bovine epithelial cells. These results represent the means and standard errors of the mean from triplicate cultures in $\mathrm{pg} / \mathrm{mL}$.

infected with T. vaginalis (Ryu et al. 2004, Scott et al. 2005). IL-10 is an important anti-inflammatory signal that is secreted by several cell populations involved in the immune response, such as macrophages, monocytes and $\mathrm{B}$ and $\mathrm{T}$ lymphocytes. Additionally, previous reports showed that IL-10 is secreted by immune cells infected with human immunodeficiency virus (HIV), thereby decreasing the number of mature dendritic cells and facili- tating viral infection (Alter et al. 2010). These data are relevant because trichomonas-positive patients are more likely to acquire HIV (Moodley et al. 2002). It is hypothesised that this might occur because of the presence of IL-10, which could interfere with cellular defence against HIV entry. Previous studies have also demonstrated that IL-10 could suppress the production of IFN- $\gamma$, TNF- $\alpha$, IL-1 and IL-8 (Moore et al. 2001).

Interestingly, IL-10 secretion was only detected when $T$. foetus, but not $T$. vaginalis, interacted with BOECs. Fichorova et al. (2006) reported that between the two species tested, only $T$. vaginalis LPG induced IL-8 secretion by human cells, thereby demonstrating that the host cell response depends on the species of trichomonad used.

Taken together, these data suggest that cytokine release does not occur when human cells are stimulated with bovine parasites or vice versa (i.e., when bovine cells are stimulated with human parasites). Thus, these results indicate that the host immune cell response is species-specific.

\section{REFERENCES}

Alter G, Kavanagh D, Rihn S, Luteijn R, Brooks D, Oldstone M, Van Lunzen J, Altfeld M 2010. IL-10 induces aberrant deletion of dendritic cells by natural killer cells in the context of HIV infection. J Clin Invest 120: 1905-1913.

Bastida-Corcuera FD, Okumura CY, Colocoussi A, Johnson PJ 2005. Trichomonas vaginalis lipophosphoglycan mutants have reduced adherence and cytotoxicity to human ectocervical cells. Eukaryot Cell 4: 1951-1958.

Bondurant RH 2005. Venereal diseases of cattle: natural history, diagnosis and the role of vaccines in their control. Vet Clin North Am Food Anim Pract 21: 383-408.

Chang JH, Park JY, Kim SK 2006. Dependence on p38 MAPK signalling in the up-regulation of TLR2, TLR4 and TLR9 gene expression in Trichomonas vaginalis-treated HeLa cells. Iтmиnology 118: 164-170.

Diamond LS 1957. The establishment of various trichomonads of animals and man in axenic cultures. J Parasitol 43: 488-490.

Fichorova RN, Trifonova RT, Gilbert RO, Costello CE, Hayes GR, Lucas JJ 2006. Trichomonas vaginalis lipophosphoglycan triggers a selective upregulation of cytokines by human female reproductive tract epithelial cells. Infect Immun 74: 5773-5779.

Han IH, Goo SY, Park SJ, Hwang SJ, Kim YS, Yang MS, Ahn MH, Ryu JS 2009. Proinflammatory cytokine and nitric oxide production by human macrophages stimulated with Trichomonas vaginalis. Korean J Parasitol 47: 205-212.

Johnston VJ, Mabey DC 2008. Global epidemiology and control of Trichomonas vaginalis. Curr Opin Infect Dis 21: 56-64.

Kirch AK, Agossou A, Banla M, Hoffmann WH, Schulz-key H, Soboslay PT 2004. Parasite-specific antibody and cytokine profiles in newborns from Plasmodium falciparum and Entamoeba histolytica/E. dispar-infected mothers. Pediat Allergy Immunol 15: 133-141.

Midlej V, Vilela R, Dias AB, Benchimol M 2009. Cytophatic effects of Tritrichomonas foetus on bovine oviduct cells. Vet Parasitol 165: 216-230.

Moodley P, Connolly C, Sturn AW 2002. Interrelationships among human immunodeficiency virus type I infection, bacterial vaginosis, trichomoniasis and the prevalence of yeasts. $J$ Infect Dis 185: 69-73. 
Moore KW, Malefyt R de W, Coffman RF, O'Garra A 2001. Interleukin-10 and the interleukin-10 receptor. Annu Rev Immunol 19: 683-765.

Ryu JS, Kang JH, Jung SY, Shin MH, Kim JM, Park H 2004. Production of interleukin- 8 by human neutrophils stimulated with Trichomonas vaginalis. Infect Immun 72: 1326-1332.

Scott K, Manunta M, Germain C, Smith P, Jones M, Mitchell P, Dessi D, Branigan Bamford K, Lechler RI, Fiori PL, Foster GR, Lombardi G 2005. Qualitatively distinct patterns of cytokines are released by human dendritic cells in response to different pathogens. Immunology 116: 245-254.
Shafir SC, Sorvillo FJ, Smith L 2009. Current issues and considerations regarding trichomoniasis and human immunodeficiency virus in African-Americans. Clin Microbiol Rev 22: 37-45.

Shaio MF, Lin PR, Liu JY, Yang KD 1995. Generation of interleukin-8 from human monocytes in response to Trichomonas vaginalis stimulation. Infect Immun 63: 3864-3870.

Singh BN, Hayes GR, Lucas JJ, Sommer U, Viseux N, Mirgorodskaya E, Trifonova RT, Sassi RR, Costello CE, Fichorova RN 2009. Structural details and composition of Trichomonas vaginalis lipophosphoglycan in relevance to the epithelial immune function. Glycoconj J 26: 3-17. 